\title{
The Nudix Hydrolase 7 is an Acyl-CoA Diphosphatase Involved in Regulating Peroxisomal Coenzyme A homeostasis.
}

\author{
Sarah-Jayne Reilly \\ Karolinska Institute \\ Veronica Tillander \\ Karolinska Institute \\ Rob Ofman \\ University of Amsterdam
}

See next page for additional authors

Follow this and additional works at: https://arrow.tudublin.ie/scschbioart

Part of the Biochemistry Commons, and the Molecular Biology Commons

\section{Recommended Citation}

Reilly, S., Tillander, V., Ofman, R., Alexson, S., Hunt, M.: The Nudix Hydrolase 7 is an Acyl-CoA Diphosphatase Involved in Regulating Peroxisomal Coenzyme A Homeostasis. Journal of Biochemistry (2008) 144(5): 655-663 doi:10.1093/jb/mvn114

This Article is brought to you for free and open access by the School of Biological Sciences at ARROW@TU Dublin. It has been accepted for inclusion in Articles by an authorized administrator of ARROW@TU Dublin. For more information, please contact arrow.admin@tudublin.ie, aisling.coyne@tudublin.ie,gerard.connolly@tudublin.ie.

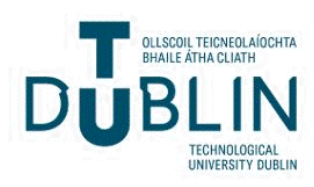




\section{Authors}

Sarah-Jayne Reilly, Veronica Tillander, Rob Ofman, Stefan Alexson, and Mary Hunt 


\title{
The nudix hydrolase 7 is an acyl-CoA diphosphatase involved in regulating peroxisomal coenzyme A homeostasis.
}

\author{
Sarah-Jayne Reilly ${ }^{1 *}$, Veronika Tillander ${ }^{1 *}$, Rob Ofman ${ }^{2}$, Stefan E. H. Alexson ${ }^{1}$ and \\ Mary C. Hunt ${ }^{3 \#}$. \\ ${ }^{1}$ Karolinska Institutet, Department of Laboratory Medicine, Division of Clinical Chemistry \\ C1-74, Karolinska University Hospital at Huddinge, SE-141 86 Stockholm, Sweden. \\ ${ }^{2}$ Department of Clinical Chemistry, Emma Children's Hospital, Academic Medical Centre, \\ University of Amsterdam, PO Box 22700, 1100 DE Amsterdam, The Netherlands. \\ ${ }^{3}$ Department of Genetics, Microbiology and Toxicology, Stockholm University, Arrhenius \\ Laboratory, Svante Arrhenius väg 16F, SE-106 91 Stockholm, Sweden.
}

*Equal contribution by authors

Short title: Nudt7 in peroxisomal acyl-CoA metabolism.

\author{
\#Corresponding author \\ Dr. Mary C. Hunt \\ Stockholm University \\ Department of Genetics, Microbiology and Toxicology \\ Arrhenius Laboratories for the Natural Sciences \\ Svante Arrhenius väg 16 E \& F, \\ SE-106 91 StockholmTelephone:
}

$+46-8-164162$

Sweden

Fax: $+46-8-164315$

e-mail: mary.hunt@gmt.su.se 


\begin{abstract}
Coenzyme $\mathrm{A}(\mathrm{CoASH})$ is an obligate cofactor for lipids undergoing $\beta$-oxidation in peroxisomes. Although the peroxisomal membrane appears to be impermeable to CoASH, peroxisomes contain their own pool of CoASH. It is believed that CoASH enters peroxisomes as acyl-CoAs, but it is not known how this pool is regulated. The mouse nudix hydrolase 7 (NUDT7 $\alpha$ ) was previously identified in peroxisomes as a CoAdiphosphatase, and therefore suggested to be involved in regulation of peroxisomal CoASH levels. Here we show that mouse NUDT7 $\alpha$ mainly acts as an acyl-CoA diphosphatase, with highest activity towards medium chain acyl-CoAs, and much lower activity with CoASH. Nudt7 $\alpha$ mRNA is highly expressed in liver, brown adipose tissue and heart, similar to enzymes involved in peroxisomal lipid degradation. Nudt7$\alpha$ mRNA is downregulated by $\mathrm{Wy}-14,643$, a peroxisome proliferator-activated receptor alpha (PPAR $\alpha$ ) ligand, in a PPAR $\alpha$ dependent manner in mouse liver. In highly purified peroxisomes, nudix hydrolase activity is highest with $\mathrm{C}_{6}-\mathrm{CoA}$ and is decreased by fibrate treatment. Under certain conditions, such as treatment with peroxisome proliferators or fasting, an increase in peroxisomal CoASH levels has been reported, which is in line with a decreased expression/activity of NUDT7 $\alpha$. Taken together these data suggest that NUDT7 $\alpha$ function is tightly linked to peroxisomal CoASH/acyl-CoA homeostasis.
\end{abstract}

Key words: peroxisomes, acyl-CoA thioesterase, peroxisome proliferator-activated receptor alpha, nudix hydrolase, coenzyme A. 


\section{INTRODUCTION}

Coenzyme A (CoASH) is involved in over 100 different reactions in intermediary metabolism and is indispensable in living organisms (for review see (1)). CoASH is an obligate co-factor in the degradation of lipids in mitochondria and peroxisomes since the $\beta$-oxidation of fatty acids requires their activation to the corresponding CoA ester before $\beta$-oxidation can proceed. This activation is catalyzed by a large family of acyl-CoA synthetases with multiple localizations in the cell (for review, see (2)). Intracellular levels of CoASH depend on the metabolic state, and CoASH is compartmentalized in cytosol, mitochondria and peroxisomes, with each organelle suggested to contain its own pool of CoASH. However, the peroxisomal membrane is impermeable to 'bulky' solutes (over $300 \mathrm{Da}$ ) including cofactors such as $\mathrm{CoASH}, \mathrm{NAD}(\mathrm{H}), \mathrm{NADP}(\mathrm{H})$, together with CoA esters of fatty acids (3). Several studies suggest that fatty acids are activated on the outside of the peroxisomal membrane, and therefore fatty acids enter peroxisomes in the form of the CoA ester (4), thus bringing CoASH into the peroxisomal lumen. Acyl-CoAs are believed to be transported across the peroxisomal membrane by a family of ATPbinding-cassette transporters ( $\mathrm{ABC}$ transporters), and to date four $\mathrm{ABC}$ transporters have been identified in mammalian peroxisomes, ABCD1-ABCD4 (for review see (4)). Peroxisomes are estimated to contain approximately $0.23-0.7 \mathrm{mM} \mathrm{CoASH}(5,6)$, which can be used for the various oxidation reactions (for review see (7)). In particular, a pool of CoASH is required for the final step in $\beta$-oxidation to proceed, catalyzed by the 3ketoacyl-CoA thiolases or the sterol carrier protein $\mathrm{x}$, where a molecule of free CoASH is 
required to form a chain-shortened acyl-CoA, with the concomitant release of acetyl-CoA or propionyl-CoA (depending on the substrate oxidized).

CoASH levels in peroxisomes can portentially be regulated by members of three enzyme families, the acyl-CoA thioesterases (ACOTs), the nudix hydrolases (NUDTs), and the carnitine acyltransferases. The ACOTs catalyze the hydrolysis of acylCoAs to the free fatty acid and CoASH (for review see (8)), while the nudix (nucleoside diphosphate linked to another moiety $\mathbf{X}$ ) hydrolases are active on CoASH and cleave CoASH to 4'-phosphopantetheine and 3',5'-ADP $(9,10)$ (see Fig. 1 for the site of hydrolysis by ACOTs and NUDT enzymes in an acyl-CoA molecule). Six ACOT enzymes have been identified in mouse peroxisomes: ACOT3-6, active on long chain acyl-CoAs, succinyl-CoA, medium chain acyl-CoAs, and branched chain acyl-CoAs respectively (11-14); ACOT8, active on a broad range of acyl-CoAs $(15,16)$; and ACOT12, active on short chain acyl-CoAs (mainly acetyl-CoA) (17). Two nudix hydrolases active on CoASH or CoA derivatives have been identified in mammalian peroxisomes, the NUDT7 (18) and NUDT19 (RP2p) (19). These enzymes function as diphosphatases that can cleave CoASH or CoA esterified to a fatty acid, with the resulting products being 4'-phosphopantetheine or acyl-phosphopantetheine (a fatty acid backbone with a 4'-phosphopantetheine) and 3',5'-ADP. The mouse NUDT7 $\alpha$ was first characterized in 2001 and expression of recombinant protein showed that this enzyme hydrolyzed CoASH, 3'-dephospho-CoA, oxidized CoA (CoASSCoA), acetyl-CoA and succinyl-CoA, with the $K_{m}$ for these substrates ranging from $230 \mu \mathrm{M}$ to $480 \mu \mathrm{M}$ (18). Two isoforms of mouse $N u d t 7$ have been identified, the $N u d t 7 \alpha$ and $N u d t 7 \beta$ (18). The NUDT7 $\alpha$ is a peroxisomal coenzyme A diphosphatase, while the $N u d t 7 \beta$ is an inactive 
splice variant. The Nudt19 was identified by proteomic analysis of mouse kidney peroxisomes as a CoA diphosphatase with activity towards CoASH, oxidized CoA and a wide range of CoA esters, including bile acid-CoAs and branched chain acyl-CoAs (19). Peroxisomes also contain two carnitine acyltransferases (carnitine acetyltransferase and carnitine octanoyltransferase) that transfer fatty acids from CoASH to carnitine for subsequent transport to mitochondria.

There are some literature reports suggesting that the peroxisomal CoASH pool is increased in liver in response to peroxisome proliferator treatment and by fasting (5). This may be due to several factors, (a) an increase in uptake of acyl-CoAs into peroxisomes under these conditions (i.e increased peroxisomal $\beta$-oxidation activity), (b) changed activities of ACOTs and carnitine acyltransferases, and (c) regulation of nudix hydrolase activity that would regulate CoASH levels in peroxisomes. Since the activity of mouse NUDT7 $\alpha$ was originally only characterized with CoASH and a very limited set of short-chain acyl-CoA's (18), we therefore set out to perform a more in-depth study on the activity of NUDT7 $\alpha$. We have examined the substrate specificity of NUDT7 $\alpha$ and show that this enzyme mainly hydrolyzes medium chain acyl-CoAs and bile acid-CoAs. We show that $N u d t 7 \alpha$ mRNA is mainly expressed in liver, brown adipose tissue and heart, tissues that also have high expression of the peroxisomal $\beta$-oxidation enzymes acyl-CoA oxidase 1 and multifunctional protein $2(20)$. The $N u d t 7 \alpha$ mRNA is downregulated in liver during conditions that alter the metabolic status of peroxisomes, such as treatment with the peroxisome proliferator-activated receptor alpha (PPAR $\alpha)$ ligand Wy-14,643. In line with this, nudix hydrolase activity was also downregulated in highly purified mouse liver peoxisomes following clofibrate treatment. Interestingly the highest nudix hydrolase 
activity in peroxisomes is with $\mathrm{C} 6-\mathrm{CoA}$ which is about 12 times higher than the activity with CoASH. Our results show that NUDT7 $\alpha$ is likely an important auxiliary enzyme in regulating peroxisomal acyl-CoA/CoASH levels, the latter being imperative for $\beta$ oxidation to proceed.

\section{Materials and methods}

\section{Cloning and expression of mouse Nudt7 $\alpha$ -}

The open reading frame of mouse Nudt7 $\alpha$ was amplified from mouse kidney total RNA using the following primers 5'-CATATGTCGCGACCTTGTGGAC-3' and 5'CATATGGGGTCTTCACAACTTGCTTAAAG-3', with NdeI sites indicated in bold. Reverse Transcriptase PCR was performed using the Takara One Step RNA PCR kit using the following program: $50^{\circ} \mathrm{C}$ for $30 \mathrm{~min}, 94^{\circ} \mathrm{C}$ for $2 \mathrm{~min}$, followed by 30 cycles of $94^{\circ} \mathrm{C}$ for $30 \mathrm{sec}, 55^{\circ} \mathrm{C}$ for $30 \mathrm{sec}$ and $72^{\circ} \mathrm{C}$ for $2 \mathrm{~min}$. The $N u d t 7 \alpha$ PCR product was cloned into the NdeI site in pET-16b vector (Novagen Corp) and fully sequenced. Alternatively, the Nudt7 $\alpha$ was cloned into the pMal-C2X vector (New England Biolabs) to express NUDT7 $\alpha$ as a fusion protein with the maltose binding protein (MBP). The Nudt7 $\alpha$ plasmid was then used to transform BL21(DES3)pLysS cells (Novagen Inc). For expression of NUDT7 $\alpha$, bacteria were cultured in Luria-Bertani medium at $37^{\circ} \mathrm{C}$, in the presence of $50 \mu \mathrm{g} / \mathrm{ml}$ ampicillin and $34 \mu \mathrm{g} / \mathrm{ml}$ chloramphenicol until an $\mathrm{A}_{600}$ of approximately 0.6 was reached. Protein expression was induced by the addition of $1 \mathrm{mM}$ isopropyl-1-thio- $\beta$-D-galactopyranoside and growth was continued for 3 hours. The bacteria were collected and frozen at $-20^{\circ} \mathrm{C}$. 
Bacterial pellets were thawed and resuspended in Bug Buster ${ }^{\mathrm{TM}}$ protein extraction reagent (Novagen Inc) with the addition of Benzonase (Novagen Inc.), incubated at room temperature for 20 minutes and centrifuged at 4,200 $\mathrm{x}$ g for $20 \mathrm{~min}$ at $4^{\circ} \mathrm{C}$. The supernatants were then used for purification of his-tagged NUDT7 $\alpha$ on a His$\operatorname{Trap}^{\mathrm{TM}}$ column (Amersham Biosciences) or purification of the MBP-fusion protein on amylose resin as described by the manufacturer (New England Biolabs). These purified fractions were subsequently used for activity measurements. Protein concentration was determined using the Bradford assay (21).

\section{Determination of recombinant nudix hydrolase activity-}

NUDT7 $\alpha$ activity was measured using two different assays. For the HPLC-based assay, NUDT7 $\alpha$ activity was measured in $100 \mathrm{mM}$ Tris/ $\mathrm{HCl}$ buffer, $\mathrm{pH} 9.0,10 \mathrm{mM} \mathrm{MgCl}_{2}$, using $200 \mu \mathrm{M}$ acyl-CoA substrates in a final volume of $125 \mu 1.10 \mathrm{mM}$ dithiothreitol (DTT) was added to incubations with CoASH to maintain it in a reduced form. Reactions were started by adding $0.8 \mu \mathrm{g}$ NUDT7 $\alpha$ and incubated for $15 \mathrm{~min}$ at $37^{\circ} \mathrm{C}$. Reactions were terminated by addition of $25 \mu \mathrm{l}$ of $2 \mathrm{M}$ perchloric acid and neutralized with potassium carbonate. Samples were centrifuged at $12,000 \mathrm{xg}$ for $10 \mathrm{~min}$ at $4^{\circ} \mathrm{C}$. Samples were diluted with an equal volume of $100 \mathrm{mM}$ ammonium phosphate (buffer A). and metabolites were analyzed on a HPLC system using a $250 \mathrm{~mm}$ x $4.6 \mathrm{~mm}$ Supelcosil LC18-S column equilibrated with buffer A at a flow rate of $1 \mathrm{ml} / \mathrm{min}$ as described in (19). The metabolites were eluted from the column with a linear gradient of 20 min changing from $100 \%$ buffer A to $100 \%$ buffer B (buffer A/acetonitrile 50:50). Absorption was measured at $260 \mathrm{~nm}$ using Chromeleon software. The specific activity was calculated 
based on measurement of 3',5'-ADP produced, using two separate NUDT7 $\alpha$ protein preparations.

For the determination of $K_{m}$ and $V_{\max }$ with different substrates, NUDT7 $\alpha$ activity was measured using an assay that is based on quantitation of released phosphate by co-incubation with alkaline phosphatase in principal as described earlier $(22,23)$. CoASH and acyl-CoAs (in the range 10-350 $\mu \mathrm{M}$ ) were incubated with 0.5-2 $\mu \mathrm{g}$ of purified recombinant NUDT7 $\alpha$ and calf intestine alkaline phosphatase $(2 \mathrm{U})$ in $100 \mathrm{mM}$ Tris/ $\mathrm{HCl}, \mathrm{pH} 8.0,5 \mathrm{mM} \mathrm{MgCl}_{2}$, in a final volume of $200 \mu \mathrm{l}$ at room temperature for 20 minutes. In the case of CoASH measurements, $10 \mathrm{mM}$ DTT was added. The incubations were terminated by addition of $700 \mu 1$ of a mixture containing ascorbic acid and ammonium molybdate in $\mathrm{H}_{2} \mathrm{SO}_{4}$ and incubated at $37^{\circ} \mathrm{C}$ for more than one hour, and the absorbance was measured at $820 \mathrm{~nm}$. The amount of free phosphate was calculated using $\mathrm{A}_{820}=0.260$ is equivalent to $10 \mathrm{nmol}$ of inorganic phosphate (Pi) (23). Control reactions without NUDT7 $\alpha$ protein were carried out for each individual substrate at each concentration to determine the NUDT7 $\alpha$ independent release of Pi by the alkaline phosphatase due to its activity towards the 3'-phosphate in CoASH (see *** in Fig.1). This background activity was subtracted from the test reaction containing NUDT7 $\alpha$ to establish the amount of NUDT7 $\alpha$-dependent Pi generated from the production of acylphosphopanthetheine (one phosphate per molecule) and 3',5'-ADP (one phosphate per molecule). The activity measurements were performed using three separate preparations of recombinant NUDT7 $\alpha$ and enzyme kinetics were calculated using Prism Enzyme Kinetics software. 


\section{Determination of nudix hydrolase activity in purified peroxisomes-}

Nudix hydrolase activity was determined in mouse liver peroxisomes from control animals or animals treated with $0.5 \%$ clofibrate for one week, isolated as described in (13). Activity was determined by incubating $50 \mu \mathrm{g}$ purified liver peroxisomes with 150 $\mu \mathrm{M} \mathrm{C}_{14}-\mathrm{CoA}$ thioether (Avanti Polar Lipids), or $250 \mu \mathrm{M} \mathrm{C}_{6}-\mathrm{CoA}$ or $250 \mu \mathrm{M}$ CoASH in $100 \mathrm{mM}$ Tris/HCl $\mathrm{pH} 8$, with or without the addition of $5 \mathrm{mM} \mathrm{MgCl} \mathrm{Me}_{2}$. Reactions were terminated by adding $50 \mu \mathrm{l}$ of $0,5 \mathrm{M}$ perchloric acid to each incubation, followed by neutralization with $2 \mathrm{M} \mathrm{KOH} / 10 \mathrm{mM}$ MES buffer until a $\mathrm{pH}$ of 6-7 was reached. Samples were then centrifuged at $14,000 \mathrm{rpm}$ for $10 \mathrm{~min}$ at $4^{\circ} \mathrm{C}$ and the supernatant was removed. $20 \mu \mathrm{l}$ of the supernatant was analyzed on a HPLC system using a 250mm x 4.6 Beckman Ultrasphere C-18 analytical column, as described above.

\section{Animals and treatments-}

Tissues were excised from adult male wild-type (+/+) mice or PPAR $\alpha$ null (-/-) mice on a pure Sv/129 background (24). The mice were fed either a standard chow diet or diets containing $0.1 \%$ Wy-14,643 (Calbiochem-Novabiochem International) or $0.5 \%(\mathrm{w} / \mathrm{w})$ clofibrate (ICI Pharmaceuticals, Macclesfield, Cheshire, UK) for 1 week before sacrifice. Animals were sacrificed by $\mathrm{CO}_{2}$ asphyxiation followed by cervical dislocation. Tissues were excised and stored at $-70^{\circ} \mathrm{C}$ for preparation of total RNA. All animal experiments were carried out with ethical permission obtained from the Animal Experimental Ethical Committee, Stockholm. 


\section{RNA isolation and cDNA synthesis-}

Total RNA was isolated from various mouse tissues using Trizol reagent (Invitrogen Corporation, CA, USA). Total RNA was treated with DNase I (Promega Corporation, Madison, WI, USA) prior to cDNA synthesis and the quality of RNA was analyzed on a 1\% agarose/formaldehyde gel. For the tissue expression studies RNA from three individual animals was pooled. For the regulation studies by Wy-14,643, three individual animals in each group were used. cDNA synthesis was performed using $1 \mu \mathrm{g}$ of total RNA using Taqman Reverse Transcription reagents (Applied Biosystems Inc). The following primers were used: Nudt7 $\alpha$ - Fwd 5'- CCGAAGTCTCCTGCTGCTAGTA -3', Rev 5'- AGCCTTGGCATCATCTATCAGA-3'; NUDT7 $\quad$ - Fwd 5'TACAGTCCCTTGAGCTGCCACA -3', Rev 5'-TTCCCAAAACCTGACTCGGTG-3'; $\beta$-actin $\quad$ - Fwd 5'-GCTTCTTtGCAGCTCCTTCGT -3', $\quad$ Rev 5'CGTCATCCATGGCGAACTG -3'. Quantitative PCR was performed in single-plex in triplicate using SYBRgreen Power master mix (Applied Biosystems Inc.) in an ABI Prism 7000 sequence detection system, using $\beta$-actin as a control, The PCR products were checked by agarose gel electrophoresis. The efficacy of all primer pairs was checked by running quantitative PCR on dilutions of template cDNA, verifying that tissue expression was analyzed in the linear range of the PCR. The average threshold (CT) values in triplicate were used to calculate the relative amounts of mRNA using the $2^{-\Delta \Delta \mathrm{CT}}$ method.

\section{RESULTS}




\section{The Nudt7 gene is alternatively spliced to encode three possible open reading frames}

We performed searches in the Expressed Sequence Tag (EST) database, which indeed revealed the existence of both $N u d t 7 \alpha$ and $N u d t 7 \beta$ (although $N u d t 7 \alpha$ is the dominating isoform with 43 of 51 ESTs corresponding to $N u d t 7 \alpha$ ). However, these searches also identified a further splice variant (designated $N u d t 7 \gamma$ ), which would result in an in-frame open reading frame that is 24 amino acids longer than $N u d t 7 \alpha$. Translation of NUDT7 $\alpha$ begins at an ATG, which results in a protein of 236 amino acids, however, NUDT7 $\gamma$ is translated from an alternative ATG start site, which is spliced out in NUDT7 $\alpha$, resulting in a protein of 260 amino acids (Fig. 2a and 2b). Again, database searches of EST clones revealed that out of 55 ESTs, only 4 corresponded to the $N u d t 7 \gamma$.

\section{The Nudt7 isoforms are mainly expressed in liver, brown adipose tissue and heart}

The tissue expression of both $N u d t 7 \alpha$ and $N u d t 7 \gamma$ was examined using real-time PCR. Nudt $7 \alpha$ showed highest expression in liver, followed by brown adipose tissue, heart and white adipose tissue (Fig. 3a). An amplicon at the 5 '-end of $N u d t 7 \gamma$ could be amplified and real-time PCR was used to examine the expression levels of the two variants relative to each other in the tissues in which $N u d t 7 \alpha$ is most highly expressed. The levels of $N u d t 7 \gamma$ are approximately 20 times lower than $N u d t 7 \alpha$, although the pattern of tissue expression was similar (Fig. 3b). Due to the very weak expression of $N u d t 7 . \gamma$, this protein was not further characterized in this study.

\section{Peroxisomal nudix hydrolase $N u d t 7 \alpha$ is regulated via the PPAR $\alpha$}


As stated previously, it has been reported that the peroxisomal CoASH pool is increased in liver in response to treatment by peroxisome proliferators. As a downregulation of nudix hydrolase activity should result in an increase in CoASH pools, we therefore examined the nudix hydrolase activity in purified peroxisomes, together with mRNA expression of $N u d t 7 \alpha$, in response to peroxisome proliferators. Interestingly, treatment with the PPAR $\alpha$ activator Wy-14,643 resulted in a decrease in Nudt7 $\alpha$ mRNA in mouse liver (Fig. 4a). This downregulation at mRNA level was not evident in the PPAR $\alpha$ knockout mouse model, showing that it is a PPAR $\alpha$ dependent effect. Keeping in mind that the cytoplasmic area of the peroxisome is increased by peroxisome proliferators (5-8 fold) $(25,26)$, it is likely that NUDT7 $\alpha$ activity is strongly decreased in relation to peroxisomal $\beta$-oxidation, which would preserve $\mathrm{CoASH}$ and may explain the increased CoASH levels seen in peroxisomes in response to peroxisome proliferator treatment.

To confirm that the decreased expression of $N u d t 7 \alpha$ mRNA is reflected in decreased nudix hydrolase activity, the activity was measured in highly purified peroxisomes isolated from control and clofibrate treated mouse liver, using $\mathrm{CoASH}, \mathrm{C}_{6^{-}}$ $\mathrm{CoA}$ and a $\mathrm{C}_{14}-\mathrm{CoA}$ thioether (the use of the $\mathrm{C}_{14}-\mathrm{CoA}$ thioether circumvents any possible interference by ACOTs when measuring nudix hydrolase activity). Interestingly, nudix hydrolase activity in peroxisomes was highest with $\mathrm{C}_{6}-\mathrm{CoA}$ (a medium chain acyl-CoA), followed by $\mathrm{C}_{14}-\mathrm{CoA}$, and much lower with CoASH (Fig. $4 \mathrm{~b}$ ). The activity towards $\mathrm{C}_{6}$ CoA and $\mathrm{C}_{14}-\mathrm{CoA}$ were reduced $70 \%$ and almost $40 \%$ respectively, following clofibrate treatment. Nudix hydrolase activity towards CoASH was however not changed in peroxisomes following clofibrate treatment. 


\section{NUDT7 $\alpha$ is a medium chain acyl-CoA diphosphatase}

The co-expression of Nudt7 $\alpha$ with straight-chain $\beta$-oxidation enzymes in liver and brown adipose tissue, together with the regulation by $\operatorname{PPAR} \alpha$ points to a role for this enzyme as an auxiliary enzyme in $\beta$-oxidation, likely in regulating $\mathrm{CoASH}$ homeostasis. The observation that nudix hydrolase activity in isolated peroxisomes is considerably higher with acyl-CoAs than with CoASH suggests that acyl-CoAs may be the preferred substrates for NUDT7 $\alpha$. We therefore expressed recombinant mouse NUDT7 $\alpha$ and reinvestigated the activity towards longer chain acyl-CoAs. The recombinant protein was very easily produced in good amounts of high purity (data not shown). Activity measurements with CoASH and various acyl-CoAs at a fixed concentration of $200 \mu \mathrm{M}$ (using the HPLC method) showed a very broad specificity, with lower enzyme activity with longer chain acyl-CoAs, and the best substrates being medium chain acyl-CoAs, choloyl-CoA and trihydroxycoprostanoyl-CoA (THCA-CoA) (Fig. 5a).

In order to determine the kinetic parameters $\left(\mathrm{V}_{\max }\right.$ and $\left.\mathrm{K}_{\mathrm{m}}\right)$ of NUDT7 $\alpha$ we used a method based on quantitation of inorganic phosphate released by co-incubation with alkaline phosphatase. Parallel incubations were carried out for each substrate and substrate concentration \pm NUDT7 $\alpha$ protein in order to determine the amount of inorganic phosphate released by alkaline phosphatase due to the NUDT7 $\alpha$ reaction. The $\mathrm{K}_{\mathrm{m}}$ values are in the range of 22 to $242 \mu \mathrm{M}$, and $\mathrm{V}_{\max }$ values between 0.13 to $1.8 \mu \mathrm{mol} / \mathrm{min} / \mathrm{mg}$. The kinetics curves for $\mathrm{CoASH}, \mathrm{C}_{6}-\mathrm{CoA}$ and $\mathrm{C}_{12}-\mathrm{CoA}$ are shown in Fig. 5b, demonstrating proper Michelis Menten kinetics, and that the method is appropriate for these measurements. Table 1 summarizes the kinetic characterization with a number of substrates, which shows that the $\mathrm{K}_{\mathrm{m}}$ values are highest with $\mathrm{CoASH}$ and short-chain acyl- 
CoAs, with substantially lower $\mathrm{K}_{\mathrm{m}}$ for medium to long chain acyl-CoAs, with the exception of $\mathrm{C} 10-\mathrm{CoA}$. The reason for the higher $\mathrm{K}_{\mathrm{m}}$ with $\mathrm{C} 10-\mathrm{CoA}$ is not clear, but was consistent between enzyme preparations and using two different commercial batches of $\mathrm{C}_{10}$-CoA. In contrast, $\mathrm{V}_{\max }$ values are much higher with medium-chain acyl-CoAs $\left(\mathrm{C}_{6^{-}}\right.$ $\mathrm{C}_{12}-\mathrm{CoA}$ ), suggesting that these acyl-CoAs are the best substrates for NUDT7 $\alpha$. It should be noted that the activity with CoASH reported here is much lower than the activity reported previously (18), however the reason for this difference is not clear. The consistently higher activities with increasing acyl chain length suggests that acyl-CoAs are the preferred substrates and the kcat and $\mathrm{kcat} / \mathrm{Km}$ values obtained with medium chain acyl-CoAs support this notion. Thus, NUDT7 $\alpha$ is a CoA diphosphatase, but the enzyme preferentially hydrolyzes medium chain acyl-CoAs and bile acid-CoAs, suggesting a role mainly in acyl-CoA metabolism.

\section{DISCUSSION}

Peroxisomes contain their own pool of CoASH, but at present intraperoxisomal CoASH homeostasis is poorly understood. The current view is that the peroxisomal membrane is impermeable to $\mathrm{CoASH}$, and no CoASH-transporter has been identified to date. Therefore it appears that $\mathrm{CoASH}$ enters peroxisomes via $\mathrm{ABC}$-transporters in the form of acyl-CoAs, and with no known mechanism of transport of CoASH out of the peroxisomes, the fate of intraperoxisomal CoASH remains unknown. There are however a number of enzymatic systems within the peroxisome that could be involved. Peroxisomes have long been known to contain short- and medium-chain carnitine 
acyltransferases that convert the CoA-ester of fatty acids to the corresponding carnitine ester for transport to mitochondria, leaving CoASH in the peroxisomal lumen. Similarly, recently identified ACOTs are likely involved in release of non-esterified fatty acids for exit out of the peroxisome, also leaving CoASH in the peroxisomal lumen (for review, see (8)). However, the recent identification of two CoASH metabolizing enzymes, NUDT7 and NUDT19, provided a very promising, and seemingly simple, explanation for metabolism of CoASH in peroxisomes. Nevertheless, this is complicated by the finding that in fact both NUDT19 (19) and NUDT7 $\alpha$ (this study) are much more active on acylCoAs rather than CoASH. Although nudix hydrolase activity in purified peroxisomes was tested on a limited number of substrates in this study, the activity pattern reveals much higher activity with medium chain acyl-CoAs $\left(\mathrm{C}_{6}-\mathrm{CoA}\right)$ and longer chain $\left(\mathrm{C}_{14}-\mathrm{Co} A\right)$ acyl-CoAs than with CoASH. This is supported by the kinetics of the recombinant Nudt7 $\alpha$ protein, with highest $\mathrm{kcat} / \mathrm{K}_{\mathrm{m}}$ values with medium to long chain acyl-CoAs. This combined data supports that NUDT7 $\alpha$ is mainly an acyl-CoA diphosphatase. Therefore, a possible function for the NUDT enzymes could be to metabolize CoA esterified to fatty acids, and thereby terminate $\beta$-oxidation. As NUD7 $\alpha$ is mainly active on medium-chain acyl-CoAs, this would allow longer-chain acyl-CoAs to undergo more cycles of $\beta$ oxidation than medium-chain acyl-CoAs and may provide an explanation as to the previously reported "function" of peroxisomal $\beta$-oxidation to act as a chain-shortening system.

The PPAR $\alpha$ is a key nuclear receptor involved in the regulation of lipid metabolism and many genes in peroxisomal $\beta$-oxidation are targets of this nuclear receptor (27). 
Conditions such as fasting and fibrate treament, which activate the PPAR $\alpha(24,28,29)$, result in an increase of peroxisomal total and free CoASH levels (5). While little is known about the regulation of nudix hydrolases under these or other conditions, microarray expression analysis shows that Nudt7 $\alpha$ is downregulated by fasting for 24 and $48 \mathrm{hr}$ in mice (30) and is also strongly upreglated by thyroid hormone (31). We now show that the Nudt7 $\alpha$ is downregulated by Wy-14,643 treatment, in a PPAR $\alpha$-dependent manner in mouse liver. Analysis of the promotor region of Nudt7 $\alpha$ reveals a direct repeat 1 (DR1 - TGACCTGTGACCT) at -959 to -971 upstream of the ATG start site, which could potentially bind the PPAR $\alpha / R X R$ heterodimer. As this is a "perfect " DR1 sequence, it is likely to be promiscuous in binding PPAR $\alpha /$ RXR heterodimers and other candidate nuclear receptors such as HNF-4 $\alpha$, COUP/TF/RXR, and RAR/RXR. Further work is however required to characterize this promotor element which is likely involved in the PPAR $\alpha$ agonist effects seen in this study. In conclusion therefore, during conditions of high requirement for $\mathrm{CoASH}$ in peroxisomes (when $\beta$-oxidation activity is high), Nudt7 $\alpha$ is downregulated to preserve CoASH in peroxisomes, which can be used in the thiolase reaction of $\beta$-oxidation.

Apart from NUDT7 $\alpha$ and NUDT19, a further nudix hydrolase has been identified in mammalian peroxisomes, named NUDT12, which is an NADH diphosphatase (32). As the peroxisomal membrane is impermeable to cofactors such as CoASH, NAD $(H)$ and $\mathrm{NADP}(\mathrm{H})$, but allows free access of small hydrophilic molecules, it has been suggested by Antonenkov et al (3) that the peroxisomal nudix hydrolases cleave bulky cofactors into two smaller molecules of approximately equal size, which 
provides a route for removal of these cofactors from peroxisomes. The role postulated for NUDT7 $\alpha$ is in the cleavage of free CoASH to 4'-phosphopantetheine and 3',5'-ADP, and thereby prevent accumulation of oxidized $\mathrm{CoASH}$ or $\mathrm{CoASH}$ in peroxisomes. The generation of 4'-phosphopantetheine in peroxisomes could theoretically be used for CoASH synthesis outside the peroxisome (for review see (1)). In mammalian cells, the first three steps of the CoA synthesis pathway are catalyzed by proteins located in the cytosol $(33,34)$, while the last two reactions take place on the outer mitochondrial membrane (35). It is therefore possible that the 4'-phosphopantetheine could be exported from peroxisomes and reused in CoASH synthesis. The fate of the 3',5'-ADP produced in peroxisomes is also unknown. In yeast and human peroxisomes, two adenine nucleotide transporters, Ant1 and PMP34, have been identified that transport adenine nucleotides across the peroxisomal membrane $(36,37)$ and therefore $3^{\prime}, 5^{\prime}$-ADP may be transported out of the peroxisome lumen. Interestingly, ADP is also a potent inhibitor of ACOT12 (38), a peroxisomal short chain acyl-CoA thioesterase that can hydrolyze mainly acetyl-CoA $(17,39,40)$, which suggests a role for nucleotides such as ADP in the regulation of acetate formation in peroxisomes.

ACOT enzymes in peroxisomes may act as a complementary system with NUDT7 $\alpha$ and NUDT19 in regulation of acyl-CoA/CoASH levels (see Fig. 1). NUDT activity with acyl-CoAs will result in formation of acyl-phosphopanthetheine and 3',5'ADP, which will be produced in parallel with ACOT enzyme products (CoASH and free fatty acids) in some tissues. This raises the question as to the fate of acylphosphopanthetheine in peroxisomes. Interestingly, preliminary data suggests that ACOT3 and ACOT8 can in fact hydrolyze the acyl-phosphopanthetheine (the product of 
the NUDT7 $\alpha$ reaction), resulting in a free fatty acid and 4'-phosphopanthetheine. This may solve some of the mystery as to why both enzyme families would use the same substrate in peroxisomes. However, further work is underway to establish the role of the ACOTs and NUDTs in regulation of peroxisomal acyl-CoA/CoA levels. 


\section{ACKNOWLEDGEMENTS}

This study is supported by the FP6 European Union Project 'Peroxisome' (LSHG-CT2004-512018), the Swedish Research Council, Svenska Sällskapet för Medicinsk

Forskning, AFA sjukförsäkrings jubileumsstiftelse, Åke Wibergs stiftelse, Lars Hiertas Minne, Fredrik och Ingrid Thurings Stiftelse, Ruth och Richard Julins Stiftelse, and Stiftelsen Professor Nanna Svartz fond.

Abbreviations: Nudt, nudix hydrolase; Acot, acyl-CoA thioesterase; PPAR $\alpha$, peroxisome proliferator-activated receptor alpha; CoASH, coenzyme A. 


\section{References}

1 Leonardi, R., Zhang, Y.-M., Rock, C. and Jackowski, S. (2005) Coenzyme A: Back in action. Prog. Lipid Res. 44, 125-153.

2 Watkins, P.A. (2008) Very-long-chain acyl-CoA synthetases. J. Biol. Chem. 283, 17731777.

3 Antonenkov, V.D., Sormunen, R.T. and Hiltunen, J.K. (2004) The rat liver peroxisomal membrane forms a permeability barrier for cofactors but not for small metabolites in vitro. J. Cell Sci. 117, 5633-5642.

4 Wanders, R.J.A., Visser, W.F., van Roermund, C.W., Kemp, S. and Waterham, H.R. (2007) The peroxisomal ABC transporter family. Pflugers Arch. 453, 719-734.

5 Horie, S., Isobe, M. and Suga, T. (1986) Changes in CoA pools in hepatic peroxisomes of the rat under various conditions. J. Biochem. 99, 1345-1352.

6 Van Broekhoven, A., Peeters, M.-C., Debeer, L.J. and Mannaerts, G.P. (1981) Subcellular distribution of coenzyme A: Evidence for a separate coenzyme a pool in peroxisomes. Biochem. Biophys. Res. Commun. 100, 305-312.

7 Wanders, R.J.A. and Waterham, H.R. (2006) Biochemistry of mammalian peroxisomes revisited. Annu. Rev. Biochem. 75, 295-332.

8 Hunt, M.C. and Alexson, S.E.H. (2008) Novel functions of acyl-CoA thioesterases and acyltransferases as auxiliary enzymes in peroxisomal lipid metabolism. Prog. Lipid Res.

10.1016/j.plipres.2008.05.001

9 Bessman, M.J., Frick, D.N. and O'Handley, S.F. (1996) The MutT proteins or "Nudix" hydrolases, a family of versatile, widely distributed, "housecleaning" enzymes. J. Biol. Chem. 271, 25059-25062.

10 McLennan, A.G. (2006) The Nudix hydrolase superfamily. Cell. Mol. Life Sci. 63, 123-143.

11 Westin, M.A.K., Alexson, S.E.H. and Hunt, M.C. (2004) Molecular cloning and characterization of two mouse peroxisome proliferator-activated receptor alpha (PPAR $\alpha$ )-regulated peroxisomal acyl-CoA thioesterases. J. Biol. Chem. 279, 2184121848.

12 Westin, M.A.K., Hunt, M.C. and Alexson, S.E.H. (2005) The identification of a succinyl-CoA thioesterase suggests a novel pathway for succinate production in peroxisomes. J. Biol. Chem. 280, 38125-38132.

13 Westin, M.A.K., Hunt, M.C. and Alexson, S.E.H. (2007) Peroxisomes contain a specific phytanoyl-CoA/pristanoyl-CoA thioesterae acting as a novel auxiliary enzyme in alpha- and beta-oxidation of methyl-branched fatty acids in mouse. J. Biol. Chem. 282, 26707-26716.

14 Hunt, M.C., Rautanen, A., Westin, M.A.K., Svensson, L.T. and Alexson, S.E.H. (2006) Analysis of mouse and human acyl-CoA thioesterase (ACOT) gene clusters shows that convergent functional evolution results in a reduced number of peroxisomal ACOTs. FASEB J. 20, 1855-1864.

15 Ofman, R., el Mrabet, L., Dacremont, G., Spijer, D. and Wanders, R.J.A. (2002) Demonstration of dimethylnonanoyl-CoA thioesterase activity in rat liver peroxisomes followed by purification and molecular cloning of the thioesterase involved. Biochem. Biophys. Res. Comm. 290, 629-634. 
16 Hunt, M.C., Solaas, K., Kase, B.F. and Alexson, S.E.H. (2002) Characterization of an acyl-CoA thioesterase that functions as a major regulator of peroxisomal lipid metabolism. J. Biol. Chem. 277, 1128-1138.

17 Suematsu, N., Okamoto, K. and Isohashi, F. (2002) Mouse cytosolic acetyl-CoA hydrolase, a novel candidate for a key enzyme involved in fat metabolism: cDNA cloning, sequencing and functional expression. Acta Biochim. Pol. 49, 937-945. 18 Gasmi, L. and McLennan, A.G. (2001) The mouse Nudt7 gene encodes a peroxisomal nudix hydrolase specific for coenzyme A and its derivatives. Biochem. J. 357, 33-38. 19 Ofman, R., Speijer, D., Leen, R. and Wanders, R.J.A. (2006) Proteomic analysis of mouse kidney peroxisomes: identification of RP2p as a peroxisomal nudix hydrolase with acyl-CoA diphosphatase activity. Biochem. J. 393, 537-543.

20 Westin, M.A.K., Hunt, M.C. and Alexson, S.E.H. (2008) Short- and medium-chain carnitine acyltransferases and acyl-CoA thioesterases in mouse provide complementary systems for transport of beta-oxidation products out of peroxisomes. Cell. Mol. Life Sci. 65, 982-990.

21 Bradford, M.M. (1976) A rapid and sensitive method for the quantitation of microgram quantities of protein utilizing the principle of protein/dye binding. Anal. Biochem. 72, 248-254.

22 Ames, B.N. (1966) Assay of inorganic phosphate, total phosphate and phosphatases. Methods in Enzymology 8, 115-118. 23 Cartwright, J.L. and McLennan, A.G. (1999) The Saccharomyces cerevisiae YOR163w gene encodes a diadenosine 5', 5"'-P1,P6-hexaphosphate (Ap6A) hydrolase member of the MutT motif (Nudix hydrolase) family. J. Biol. Chem. 274, 8604-8610. 24 Lee, S.S., Pineau, T., Drago, J., Lee, E.J., Owens, J.W., Kroetz, D.L., FernandezSalguero, P.M., Westphal, H. and Gonzalez, F.J. (1995) Targeted disruption of the alpha isoform of the peroxisome proliferator-activated receptor gene in mice results in abolishment of the pleiotropic effects of peroxisome proliferators. Mol. Cell. Biol. 15, 3012-3022.

25 Zhang, X., Tanaka, N., Nakajima, T., Kamijo, Y., Gonzalez, F.J. and Aoyama, T. (2006) Peroxisome proliferator-activated receptor alpha-independent peroxisome proliferation. Biochem. Biophys. Res. Commun. 346, 1307-1311.

26 Meijer, J., Starkerud, C., Granell, I. and Afzelius, B.A. (1991) Time-dependent effects of the hypolipidemic agent clofibrate on peroxisomes and mitochondria in mouse hepatocytes. J. Submicrosc. Cytol. Pathol. 23, 185-194.

27 Mandard, S., Müller, M. and Kersten, S. (2004) Peroxisome proliferator-activated receptor $\alpha$ target genes. Cell. Mol. Life Sci. 61, 393-416.

28 Kersten, S., Seydoux, J., Peters, J.M., Gonzalez, F.J., Desvergne, B. and Wahli, W. (1999) Peroxisome proliferator-activated receptor $\alpha$ mediates the adaptive response to fasting. J. Clin. Invest. 103, 1489-1498.

29 Leone, T.C., Weinheimer, C.J. and Kelly, D.P. (1999) A critical role for the peroxisome proliferator-activated receptor $\alpha(\operatorname{PPAR} \alpha)$ in the cellular fasting response: The PPAR $\alpha$-null mouse as a model of fatty acid oxidation disorders. Proc. Natl. Acad. Sci. U.S.A. 96, 7473-7478.

30 Bauer, M., Hamm, A.C., Bonaus, M., Jacob, A., Jaekel, J., Schorle, H., Pankratz, M.J. and Katzenberger, J.D. (2004) Starvation response in mouse liver shows strong correlation with life-span-prolonging processes. Physiol. Genomics 17, 230-244. 
31 Flores-Morales, A., Gullberg, H., Fernandez, L., Stålberg, N., Lee, N.H., Vennström, B. and Norstedt, G. (2002) Patterns of liver gene expression governed by TRbeta. Mol. Endocrinol. 16, 1257-1268.

32 AbdelRaheim, S.R., Spiller, D.G. and McLennan, A.G. (2003) Mammalian NADH diphosphatases of the Nudix family: cloning and characterization of the human peroxisomal NUDT12 protein. Biochem J 374, 329-335.

33 Aberhart, D.J., Ghoshal, P.K., Cotting, J.A. and Russell, D.J. (1985) Coenzyme A biosynthesis: steric course of 4'-phosphopantothenoyl-L-cysteine decarboxylase. Biochemistry 24, 7178-7182.

34 Scandurra, R., Barboni, E., Granata, F., Pensa, B. and Costa, M. (1974)

Pantothenoylcysteine-4' -phosphate decarboxylase from horse liver. Eur. J. Biochem. 49, $1-9$.

35 Zhyvoloup, A., Nemazanyy, I., Panasyuk, G., Valovka, T., Fenton, T., Rebholz, H., Wang, M.L., Foxon, R., Lyzogubov, V., Usenko, V., Kyyamova, R., Gorbenko, O., Matsuka, G., Filonenko, V. and Gout, I.T. (2003) Subcellular localization and regulation of coenzyme A synthase. J. Biol. Chem. 278, 50316-50321.

36 Palmieri, L., Rottensteiner, H., Girzalsky, W., Scarcia, P., Palmieri, F. and Erdmann, R. (2001) Identification and functional reconstitution of the yeast peroxisomal adenine nucleotide transporter. EMBO J. 20, 5049-5059.

37 Visser, W.F., van Roermund, C.W., Waterham, H.R. and Wanders, R.J. (2002) Identification of human PMP34 as a peroxisomal ATP transporter. Biochem. Biophys. Res. Commun. 299, 494-497.

38 Söling, H.-D. and Rescher, C. (1985) On the regulation of cold-labile cytosolic and of mitochondrial acetyl-CoA hydrolase in rat liver. Eur. J. Biochem. 147, 111-117.

39 Prass, R.L., Isohashi, F. and Utter, M.F. (1980) Purification and characterization of an extramitochondrial acetyl coenzyme A hydrolase from rat liver. J. Biol. Chem. 255, 5215-5223.

40 Suematsu, N., Okamoto, K., Shibata, K., Nakanishi, Y. and Isohashi, F. (2001) Molecular cloning and functional expression of rat liver cytosolic acetyl-CoA hydrolase. Eur. J. Biochem. 268, 2700-2709. 
Table 1. Kinetic characterization of NUDT7 $\alpha$.

Diphosphatase activity of recombinant NUDT7 $\alpha$ was measured on three protein preparations (shown as mean \pm S.E.M.). $\mathrm{K}_{\mathrm{m}}$ and $\mathrm{V}_{\max }$ values were calculated using Prism Enzyme Kinetics software, and were used to calculate kcat and kcat $/ \mathrm{K}_{\mathrm{m}}$.

\begin{tabular}{|l|c|c|c|c|}
\hline \multicolumn{1}{|c|}{ Acyl-CoA } & $\begin{array}{c}\mathbf{V}_{\mathbf{m a x}} \\
(\boldsymbol{\mu} \mathbf{m o l} / \mathbf{m i n} / \mathbf{m g})\end{array}$ & $\mathbf{K}_{\mathbf{m}}(\boldsymbol{\mu} \mathbf{M})$ & Kcat (1/s) & $\begin{array}{c}\mathbf{k c a t} / \mathbf{K}_{\mathbf{m}} \\
(\mathbf{m M})\end{array}$ \\
\hline CoASH & $0.13 \pm 0.08$ & $157.0 \pm 40.5$ & $0.06 \pm 0.04$ & $0.48 \pm 0.34$ \\
\hline Acetyl $\left(\mathrm{C}_{2}-\mathrm{CoA}\right)$ & $0.27 \pm 0.04$ & $132.8 \pm 15.9$ & $0.12 \pm 0.02$ & $0.95 \pm 0.05$ \\
\hline Propionyl $\left(\mathrm{C}_{3}-\mathrm{Co} \mathrm{A}\right)$ & $0.33 \pm 0.04$ & $221.4 \pm 35$ & $0.15 \pm 0.02$ & $0.73 \pm 0.06$ \\
\hline Butyryl $\left(\mathrm{C}_{4}-\mathrm{Co} \mathrm{A}\right)$ & $0.49 \pm 0.06$ & $157.9 \pm 34.4$ & $0.23 \pm 0.02$ & $1.61 \pm 0.32$ \\
\hline Hexanoyl $\left(\mathrm{C}_{6}-\mathrm{Co} \mathrm{A}\right)$ & $0.83 \pm 0.144$ & $92.6 \pm 18.0$ & $0.39 \pm 0.06$ & $4.34 \pm 0.75$ \\
\hline Octanoyl $\left(\mathrm{C}_{8}-\mathrm{CoA}\right)$ & $1.08 \pm 0.17$ & $62.6 \pm 9.6$ & $0.51 \pm 0.08$ & $8.26 \pm 0.92$ \\
\hline Decanoyl $\left(\mathrm{C}_{10}-\mathrm{Co} \mathrm{A}\right)$ & $1.84 \pm 0.17$ & $242.0 \pm 10.0$ & $0.87 \pm 0.08$ & $3.58 \pm 0.17$ \\
\hline Lauroyl $\left(\mathrm{C}_{12}-\mathrm{Co} \mathrm{A}\right)$ & $1.06 \pm 0.14$ & $22.4 \pm 2.3$ & $0.50 \pm 0.06$ & $22.26 \pm 1.51$ \\
\hline Myristoyl $\left(\mathrm{C}_{14}-\mathrm{CoA}\right)$ & $0.41 \pm 0.04$ & $34.0 \pm 13.2$ & $0.19 \pm 0.01$ & $8.14 \pm 3.49$ \\
\hline Palmitoyl $\left(\mathrm{C}_{16}-\mathrm{Co} \mathrm{A}\right)$ & $0.15 \pm 0.10$ & $28.7 \pm 14.9$ & $0.07 \pm 0.04$ & $6.85 \pm 4.96$ \\
\hline
\end{tabular}




\section{FIGURE LEGENDS}

Fig. 1. Reaction catalyzed by acyl-CoA thioesterases (ACOTs) and nudix hydrolases (NUDTs). The ACOTs hydrolyze acyl-CoAs to produce a free fatty acid and free CoASH, while NUDT7 $\alpha$ will produce 4'-phosphopanthetheine or a fatty acid with a phosphopantetheine attached (4'-acyl-phosphopantetheine) and 3',5'-ADP. The arrows indicate the sites of hydrolysis by ACOTs and NUDTs. The fatty acid (n) represents the acyl group. ${ }^{* * *}$ is the $3^{\prime}$ phosphate on the CoASH.

Fig. 2. Structural organization of the mouse Nudt7 gene. (a) Database searches in mouse identified a gene for Nudt7 that codes for 2 splice variants. The first variant $N u d t 7 \alpha$ contains the first in-frame ATG and results in a protein that is 236 amino acids. In the second alternatively spliced variant, $N u d t 7 \gamma$, the first ATG is spliced out and translation begins at position 1667 to produce a protein that is 260 amino acids. (b) Alignment of the amino acid sequences of NUDT7 $\alpha$ and NUDT7 $\gamma$. Identical amino acids are shaded.

Fig. 3. Nudt7 $\alpha$ is mainly expressed in liver and brown adipose tissue.

(a) Tissue expression of $N u d t 7 \alpha$ was examined by single-plex Q-PCR in various tissues from male Sv/129 mice using $\beta$-actin as an endogenous control. Samples from three animals were pooled and run in triplicate and the relative amounts of mRNA were calculated using the $2^{-\Delta \Delta \mathrm{CT}}$ method. (b) The expression levels of $N u d t 7 \alpha$ and $N u d t 7 \gamma$ were compared by Q-PCR in liver, BAT, heart, WAT and kidney. $\beta$-actin was used as an endogenous control and the $2^{-\Delta \Delta \mathrm{CT}}$ method was used to calculate the expression levels that 
are presented as percentage of the $N u d t 7 \alpha$ expression in liver (the tissue with the highest expression). BAT; brown adipose tissue, WAT; white adipose tissue, Prox. I; proximal intestine (first $10 \mathrm{~cm}$ of the small intestine), Dist. I; distal intestine (last $10 \mathrm{~cm}$ of the small intestine).

Fig. 4. The expression and activity of $N u d t 7 \alpha$ is regulated by the PPAR $\alpha$. (a) Regulation of expression of $N u d t 7 \alpha$ mRNA by treatment of mice with $0.1 \%$ Wy-14,643 for 1 week was examined in liver using wildtype (+/+) and PPAR $\alpha$-null mice (-/-) using single-plex Q-PCR. Samples were run in triplicate from three individual animals for each group, and the relative amounts of mRNA were calculated using the $2^{-\Delta \Delta C T}$ method. (b) Nudix hydrolase activity was measured in purified liver peroxisomes from control mice and mice treated with $0.5 \%(\mathrm{w} / \mathrm{w})$ clofibrate for one week. Activity was measured using HPLC as described in experimental procedures, with $250 \mu \mathrm{M} \mathrm{CoASH}$ or $\mathrm{C}_{6}$-CoA or 150 $\mu \mathrm{M} \mathrm{C}_{14}-\mathrm{CoA}$ thioether. The data shown are the means of duplicate incubations with each substrate.

Fig. 5. Kinetic characterization of NUDT7 $\alpha$. (a) NUDT7 $\alpha$ was expressed in Escherichia coli, and the recombinant protein was used to measure the activity with CoASH, short-, medium- and long-chain acyl-CoAs, bile acid-CoA esters, and methyl branched CoA esters (at $200 \mu \mathrm{M}$ ) by HPLC as described in experimental procedures. Two different protein preparations $(0.8 \mu \mathrm{g})$ were used to measure the activity, for which the mean values are shown. THCA, trihydroxycoprostanoyl-CoA. (b) NUDT7 $\alpha$ activity was measured for $\mathrm{CoASH}$ (i), $\mathrm{C}_{6}-\mathrm{CoA}$ (ii) and $\mathrm{C}_{12}-\mathrm{CoA}$ (iii) at various substrate 
concentrations. Enzyme kinetics were calculated using the Prism Enzyme Kinetics software. 


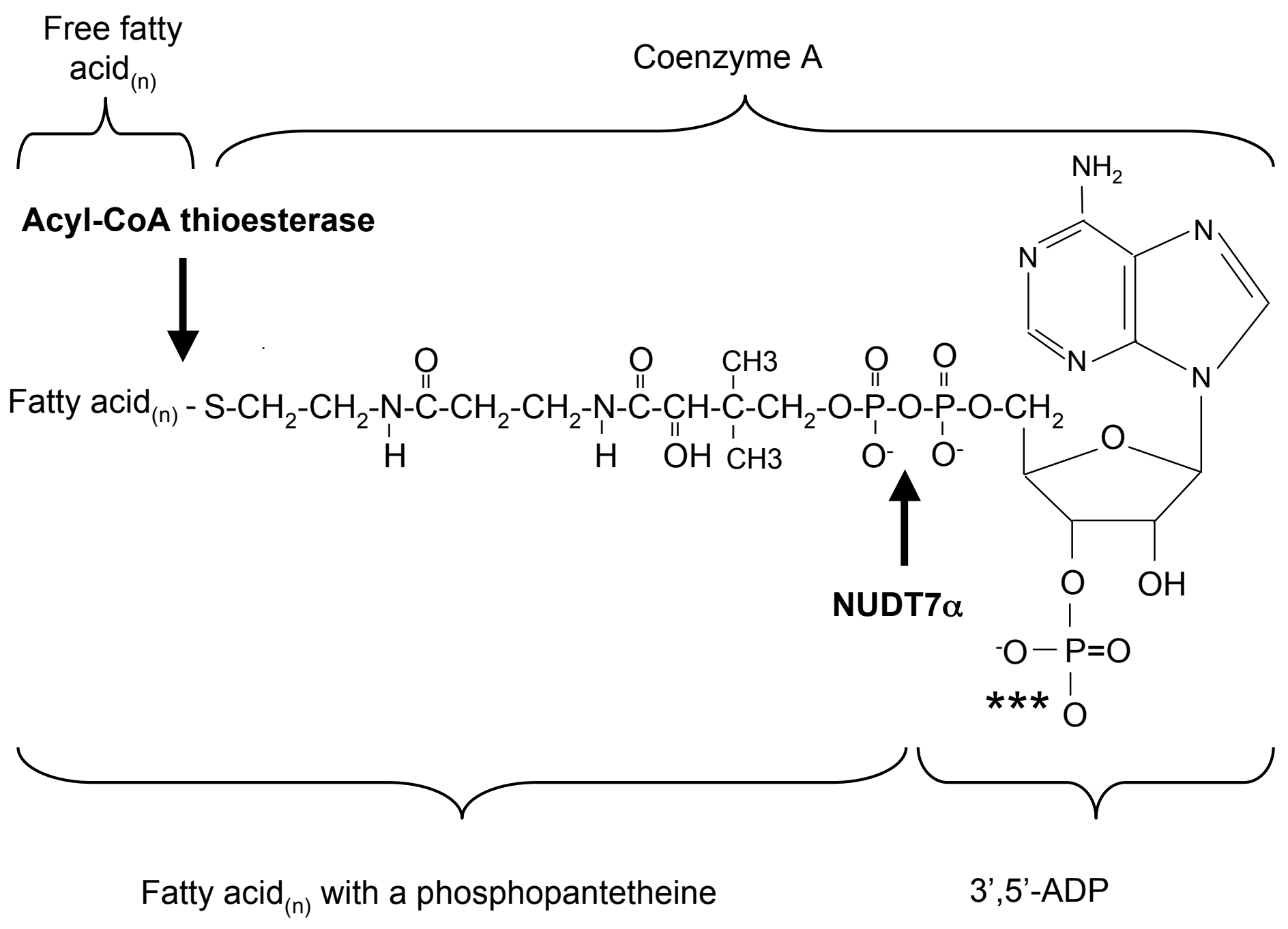

Nudix hydrolase reaction products 
a

a

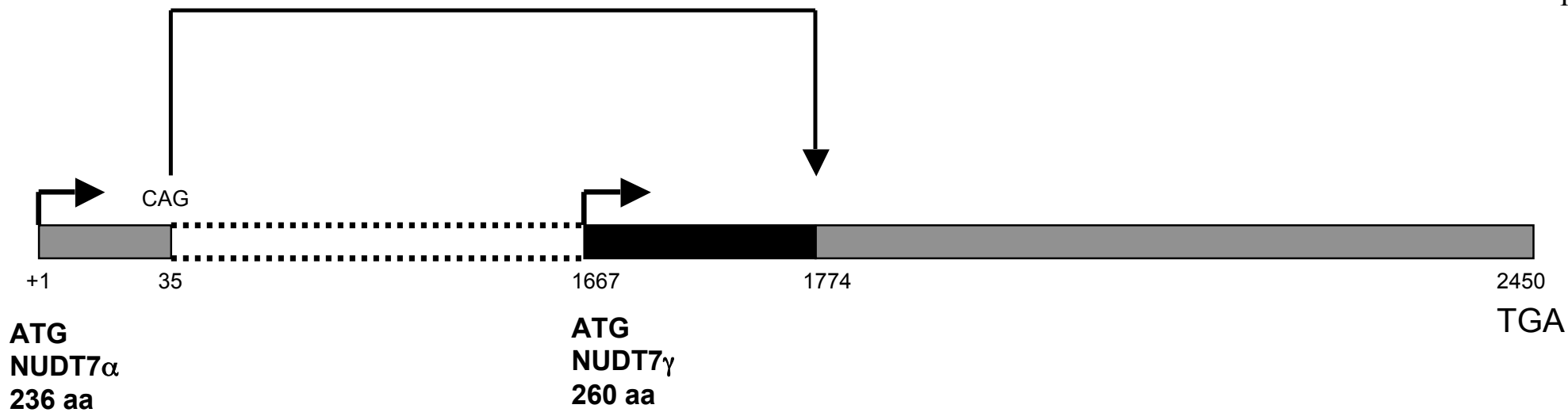

b

1

1 MVQSLELPQRQPCHFGSWIKRSPSGLTSKSPSQVLGN NLI NUDT7

17 D D A K ARLRKSDVGTRYSHLSSNKFS VLVPLLARGGKL Y L M NUDT7 $\alpha$

41 D D A K ARLRKSDVGTRYSHLSSNKFSVLVPLLARGGKLYLM NUDT7\%

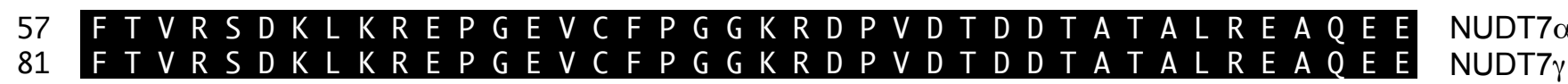

97 V GLH P H Q VE V V S H L V P Y V F D N D A L V T P V V G F L D H N F Q A Q P NUDT7 $\alpha$

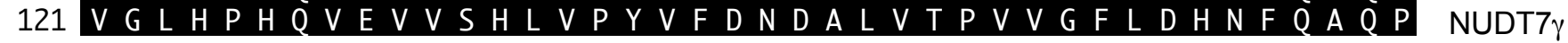

137 N A D E V K E V F F V P L D Y F L H P Q V Y Y Q K Q I T Q S G R D F I M H C F E NUDT7 $\alpha$

161 N A DEVKEVFFV PLDYFLHPQVYYQK OITOSGRDFIMHCFE NUDT7

177 Y K D P E T G V N Y L I Q G M T S K L A V L V A L I I L E Q S P A F K I D F D L NUDT7a

201 Y K D P E T G V N Y L I Q G M T SKLA V L VALIILE Q S P A F K I D F D L NUDT7

$\begin{array}{llllllllllllllll}217 & \text { H D L L I P S C E R T F L W R Y S L S K L } & \text { NUDT7 } \alpha \\ 241 & \text { H D L L I P S C E R T F L W R Y S L S K L } & \text { NUDT7 }\end{array}$ 
a

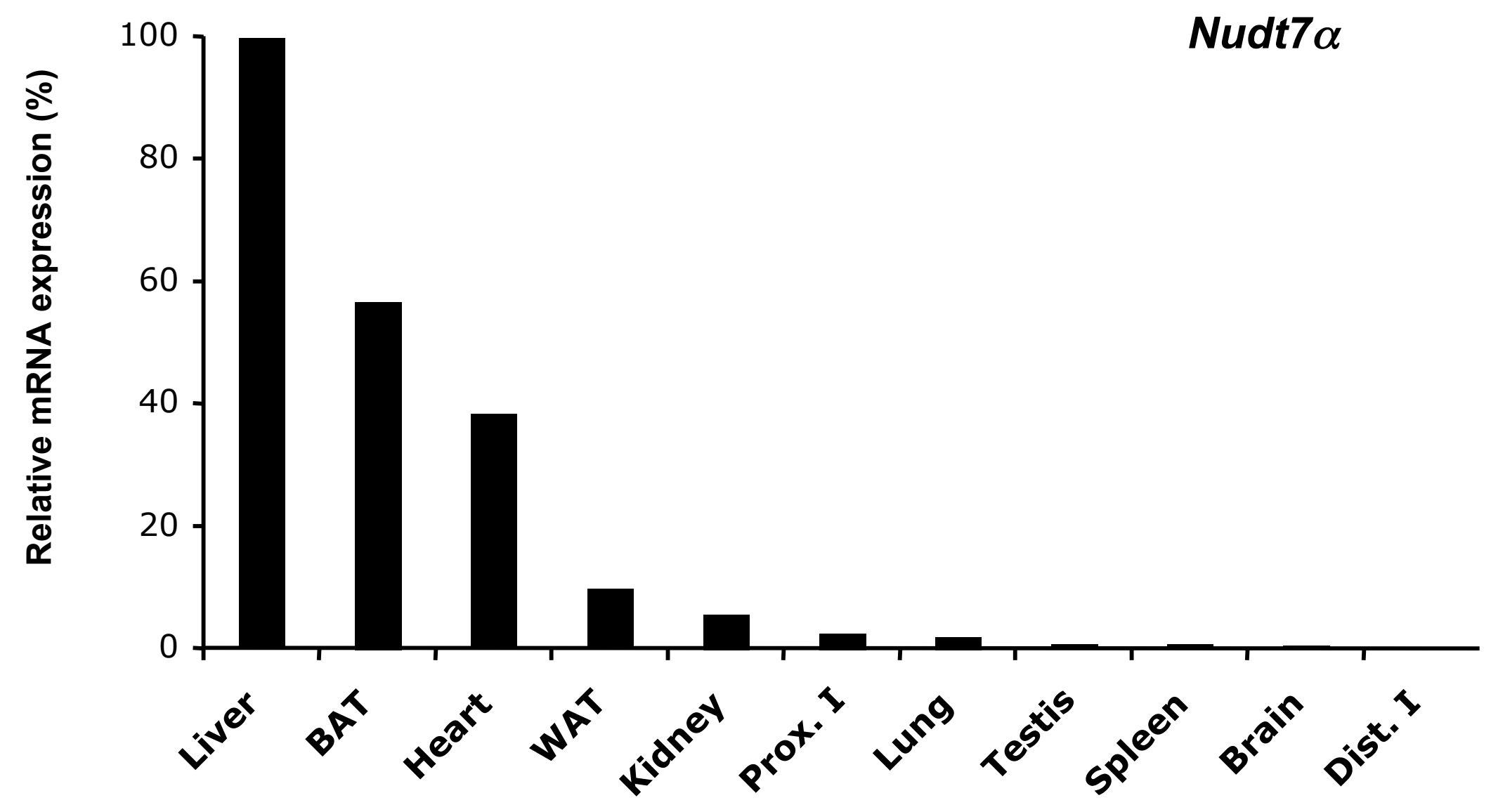


b

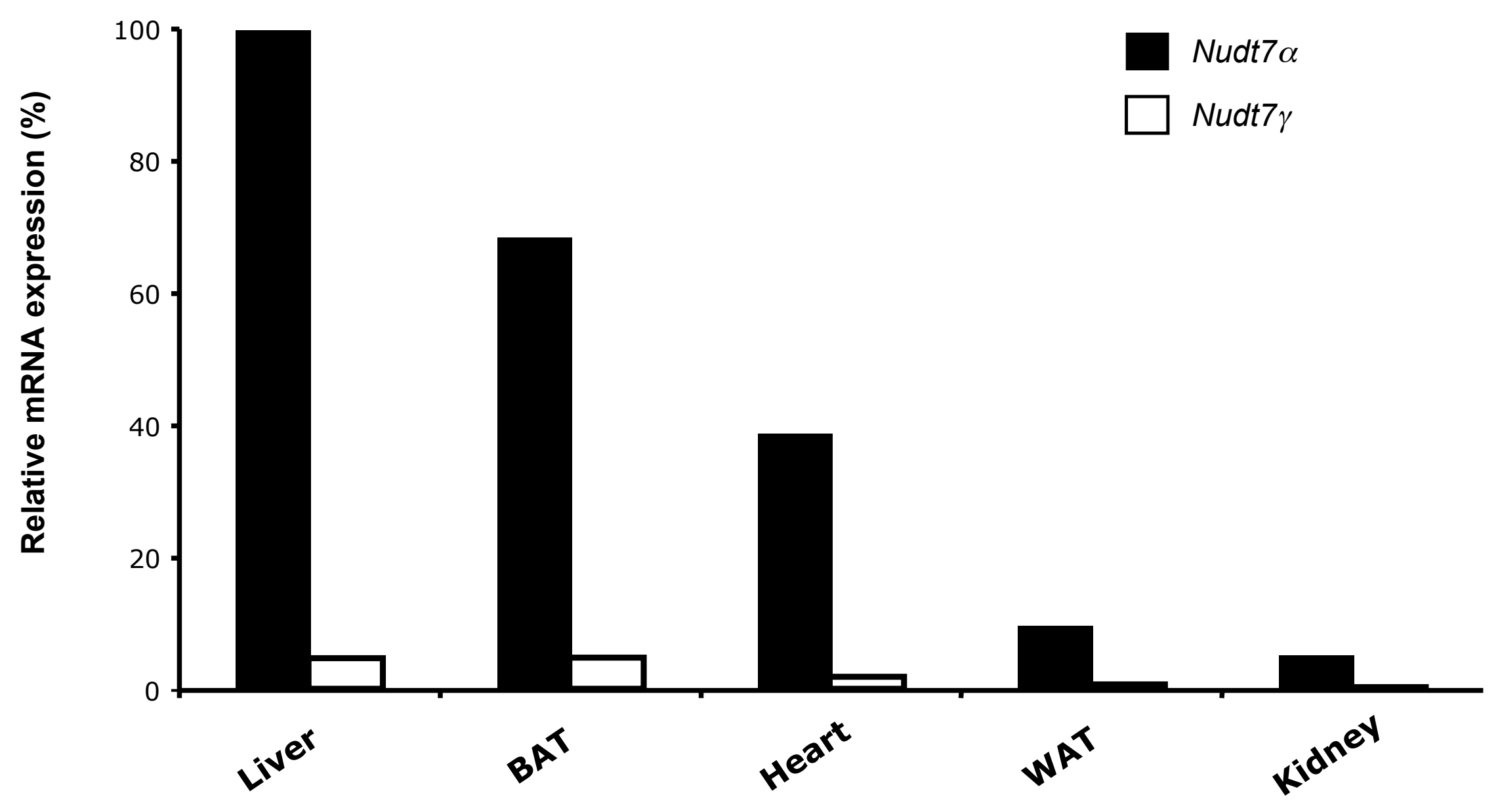


a

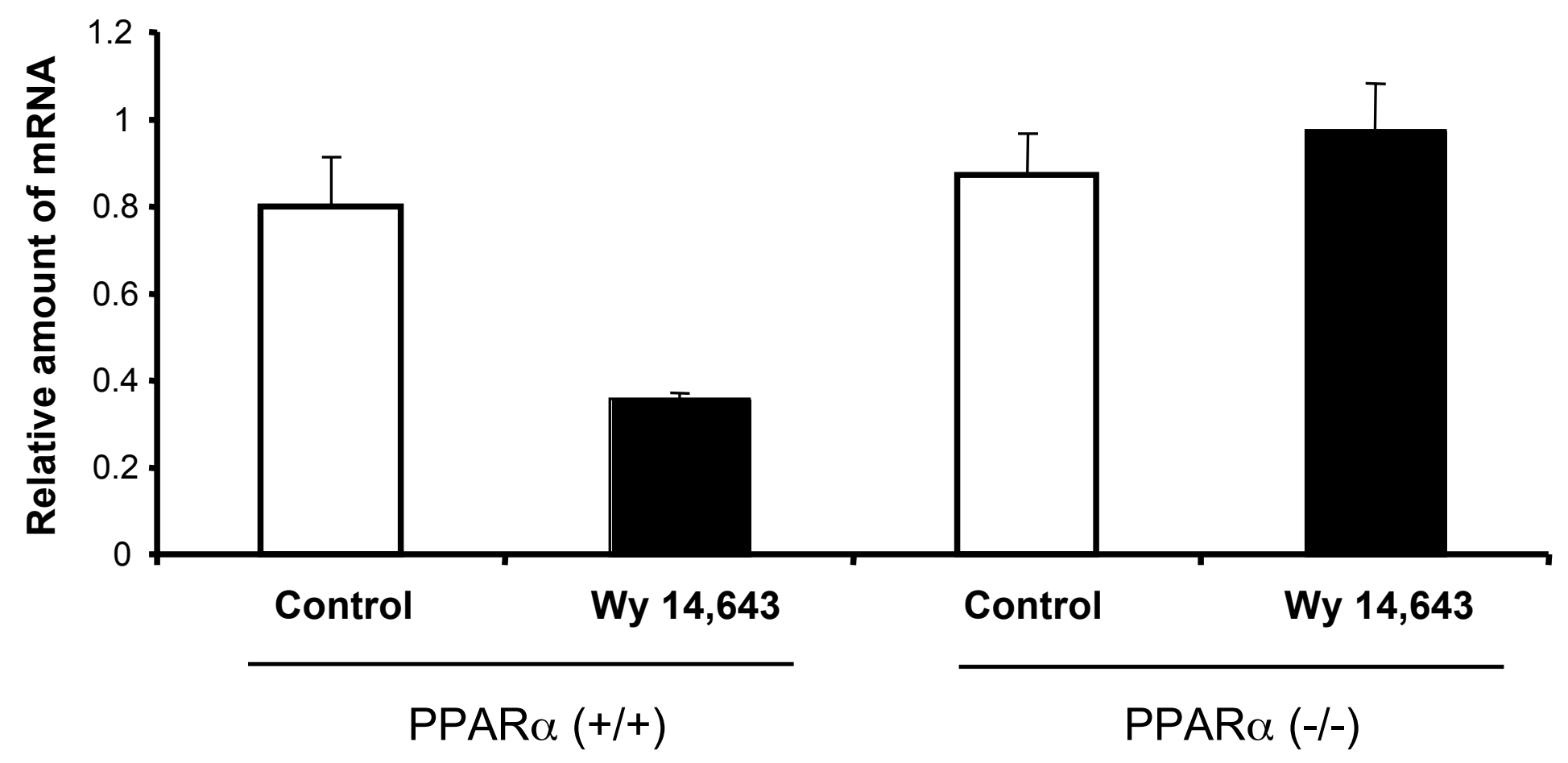


Fig. 4

b

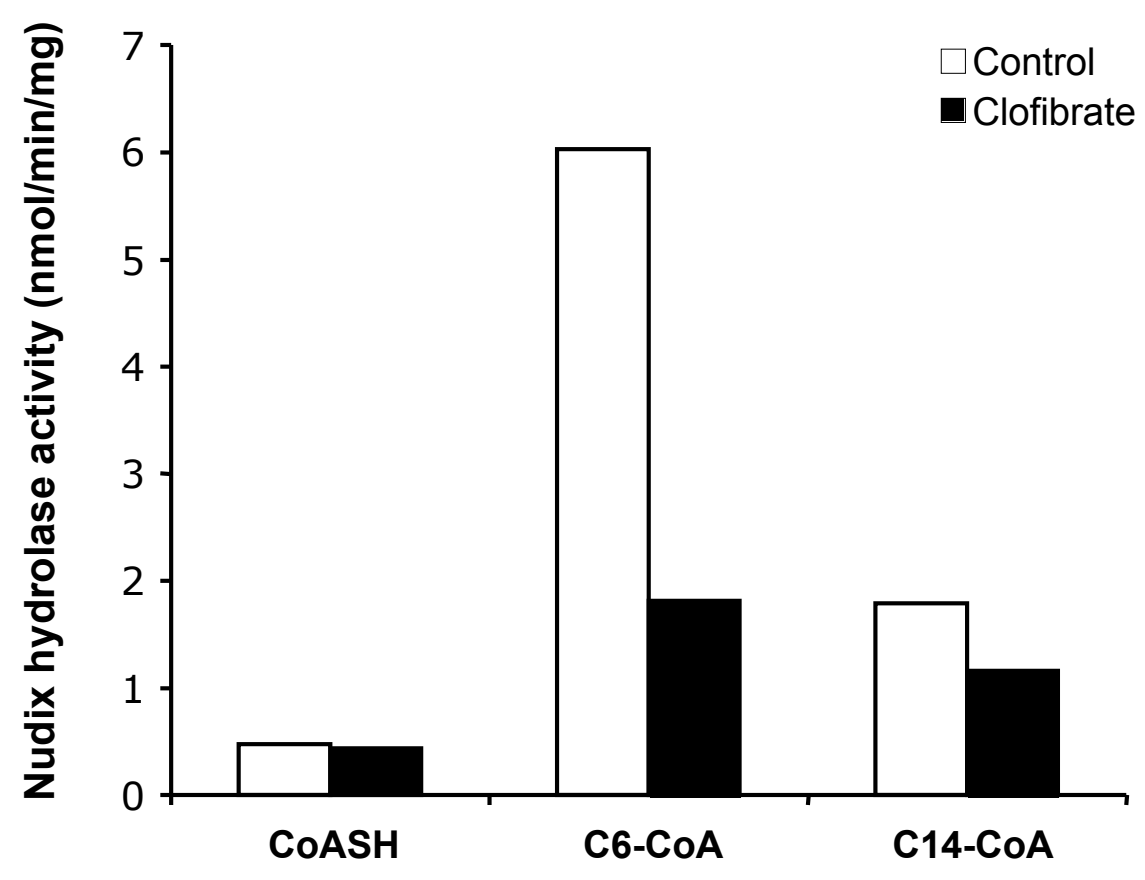




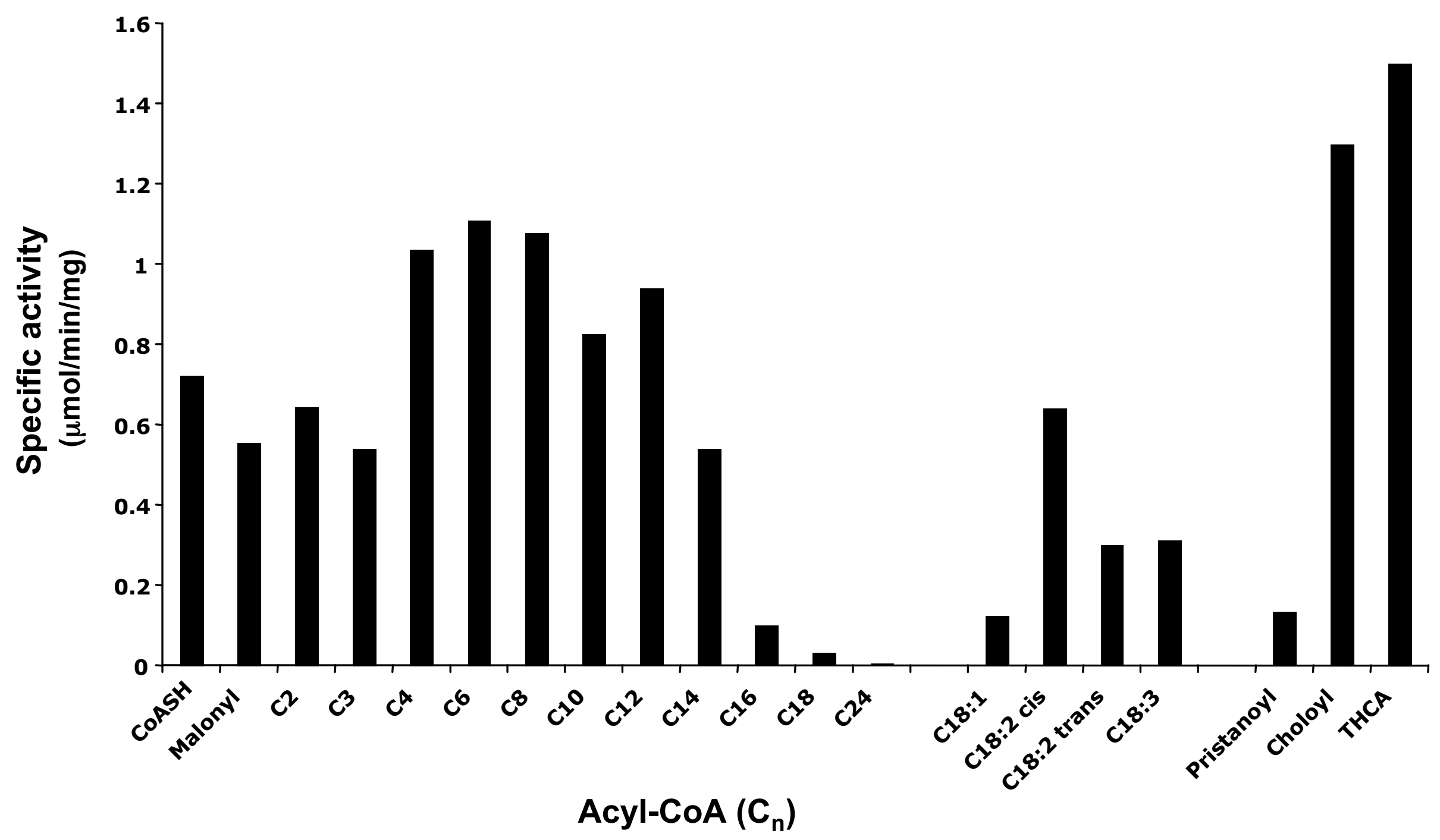


b

Fig. 5.

(i)

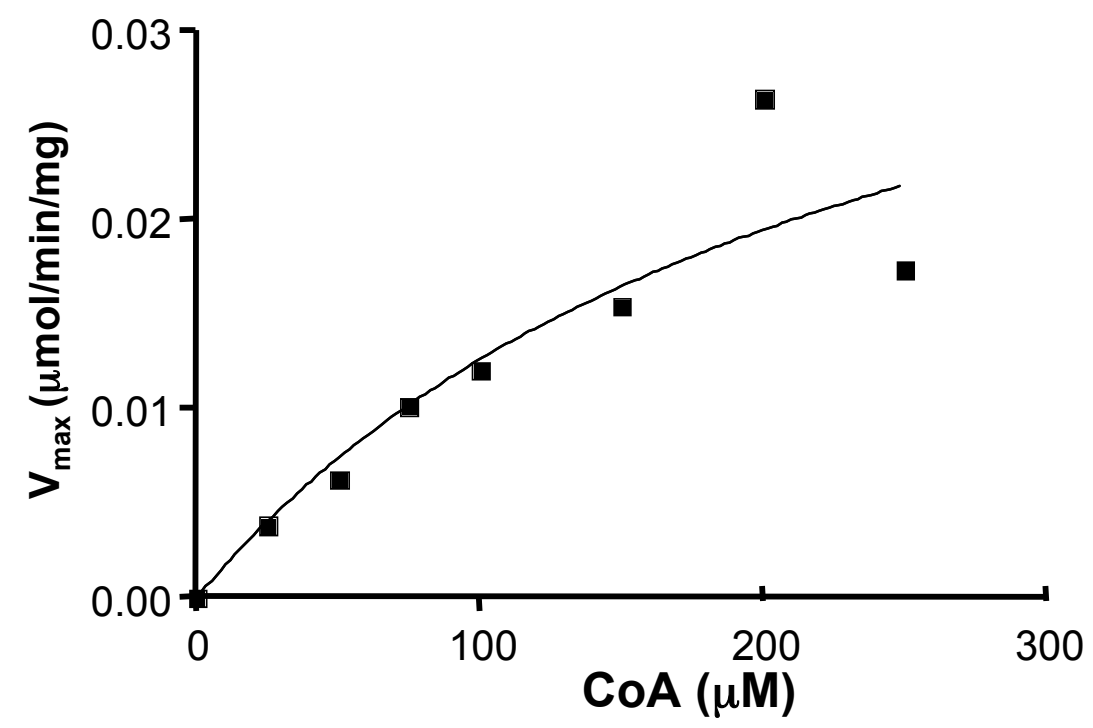

(ii)

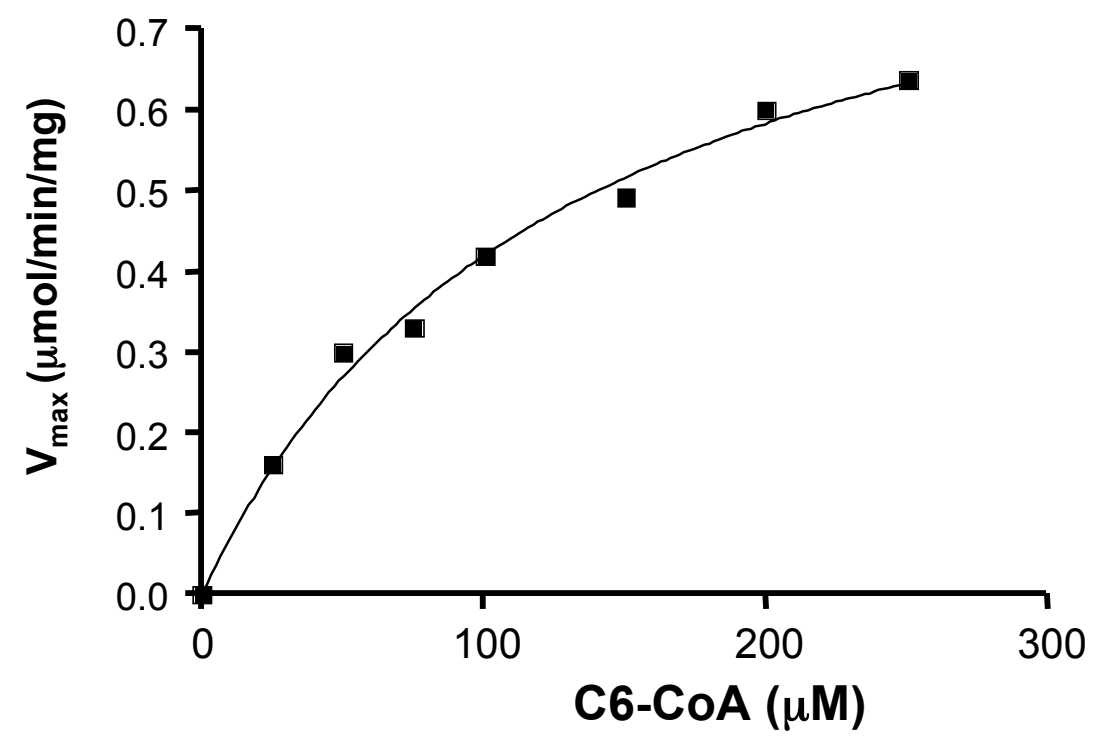

(iii)

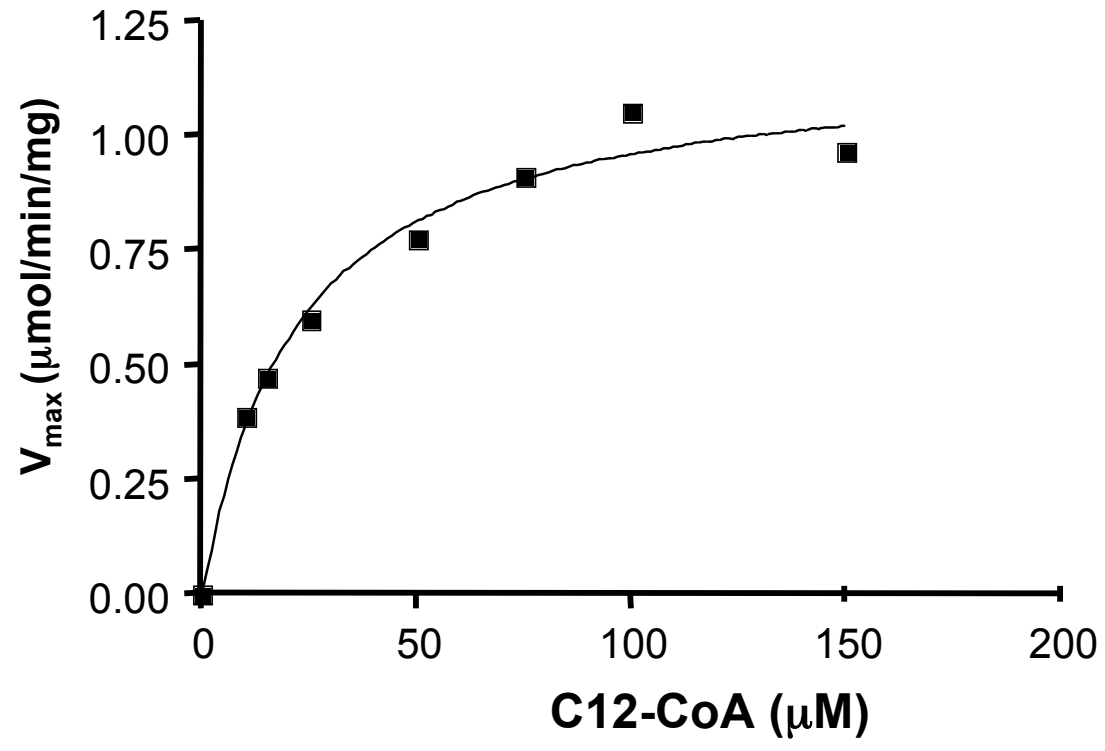

